\title{
ARTIKELEN
}

\section{Actuele opvattingen inzake civiel schadeverhaal via het strafproces ${ }^{*}$}

\author{
Renée Kool \& Jessy Emaus
}

\section{$1 \quad$ Inleiding}

Onlangs verscheen van onze hand het rapport Civiel schadeverhaal via het strafproces. ${ }^{1}$ Aanleiding tot het onderzoek was de opdracht van het Wetenschappelijk Onderzoek- en Documentatiecentrum (WODC) om te bezien hoe de voegingspraktijk anno 2016 verloopt, in het bijzonder gelet op de in 2010 ingevoerde wijziging van het voegingscriterium (art. 361 lid 3 van het Wetboek van Strafvordering (Sv)). Maar ook anderszins was er voldoende aanleiding voor deze verkenning. Sinds de laatste evaluatie van $2007^{2}$ zijn er namelijk verschillende onderzoeken verschenen, ${ }^{3}$ werden beleidsmaatregelen getroffen en werd de Handleiding van de Raad voor de rechtspraak gepubliceerd. ${ }^{4}$

Uit de onderzoeken komt ondubbelzinnig naar voren dat slachtoffers groot belang hechten aan schadevergoeding en een voorkeur hebben voor verhaal via het strafproces. Overwegingen inzake procedurele rechtvaardigheid dragen daar, naast de aan het strafrechtelijk traject verbonden executoriale voordelen, ${ }^{5}$ aan bij. Er is, anders gezegd, geen ontsnappen aan voor de strafrechtspleging. De vraag ook is of men dat zou willen. Een antwoord op die vraag ligt besloten in de interviews die ten behoeve van ons onderzoek naar civiel schadeverhaal zijn gehouden.

* Dr. Renée Kool is universitair hoofddocent Strafrecht aan de Universiteit Utrecht en als onderzoeker verbonden aan het Utrechtse onderzoekscentrum Ucall. Mr. dr. Jessy Emaus is universitair docent Privaatrecht aan de Universiteit Utrecht en als onderzoeker verbonden aan de Utrechtse onderzoekscentra Ucall en Renforce, en is SIM-fellow.

1 R.S.B. Kool e.a., Civiel schadeverhaal via het strafproces. Een verkenning van de rechtspraktijk en regelgeving betreffende de voeging benadeelde partij, Den Haag: Boom juridisch 2016. De digitale versie is te downloaden via: www.wodc.nl/onderzoeksdatabase/2569-schadeverhaal-door-civielevoeging-in-het-strafproces.aspx.

2 S. van Wingerden e.a., De praktijk van schadevergoeding voor slachtoffers van misdrijven, Den Haag: WODC/Boom Juridische uitgevers 2007.

3 W.M. Schrama \& T. Geurts, Civiel schadeverhaal door slachtoffers van delicten. De rol van de civiele procedure: gebruik, knelpunten en oplossingsrichtingen, Den Haag: WODC 2012; J.D.W.E. Mulder, Compensation, the victim's perspective, Oisterwijk: Wolf 2013; J.D.M. van Dongen e.a., Je hebt geluk als je van een pauw mag plukken, Rotterdam: EUR 2013; R.S.B. Kool e.a., Schadeverhaal na een strafbaar feit via de kantonrechter, Den Haag: Boom Juridische uitgevers 2014.

4 J. Candido e.a., Slachtoffer en rechtspraak. Handleiding voorde strafrechtspraktijk, Den Haag: Raad voor de rechtspraak 2013.

5 Gedoeld wordt op de oplegging van de schadevergoedingsmaatregel (art. 36f Sr) en de daaraan verbonden executie door het CJIB, alsmede op de Voorschotregeling. 
Daarin zijn rechters, officieren van justitie ${ }^{6}$ en advocaten ${ }^{7}$ gevraagd naar hun opvattingen over de plaats en betekenis van civiel schadeverhaal via het strafproces. ${ }^{8}$ Zijn die opvattingen gewijzigd ten opzichte van wat daarover is opgetekend in de evaluatie van $2007 ?^{9}$ En hoe komen deze opvattingen tot uitdrukking in de besluitvorming inzake het civiele schadeverhaal? Voordat we dit aandachtspunt uitwerken, besteden we kort aandacht aan de opzet van het onderzoek en noemen we de belangrijkste bevindingen.

\section{Onderzoeksopzet}

\subsection{Vier deelonderzoeken}

Het onderzoek is breed opgezet. Naast een uitgebreide verkenning van regelgeving en jurisprudentie is aandacht besteed aan de voorbereiding van de vordering van de benadeelde partij via de Slachtofferloketten en de advocatuur. Voorts zijn trendgegevens verzameld, is een uitgebreid dossieronderzoek verricht en zijn semigestructureerde interviews gehouden met professionals die werkzaam zijn ten behoeve van de voorbereiding van de vordering en met professionals die betrokken zijn bij de afhandeling daarvan. Tot slot is een rechtstheoretische verkenning uitgevoerd naar vier rechtsfiguren teneinde te bezien in hoeverre toepassing daarvan geconstateerde problemen zou kunnen wegnemen. Door te kiezen voor een combinatie van onderzoeksmethoden (triangulatie) werden de validiteit en de betrouwbaarheid van de uitkomsten uit de deelonderzoeken geoptimaliseerd en kon de problematiek integraal in beeld worden gebracht. ${ }^{10}$

\subsection{De interviews}

Toegespitst op de opvattingen van de strafrechtelijke professionals werden semigestructureerde interviews ${ }^{11}$ afgenomen met 23 respondenten: 9 rechters, 7 officieren van justitie en 7 advocaten. Deze respondenten zijn niet at random geworven, maar via aanlevering vanuit de organisatie, dan wel vanuit een aanwezig netwerk (zogeheten snowball-sampling). ${ }^{12}$ Voorafgaand waren ter verkenning van de voorbereiding van de voeging benadeelde partij 17 semigestructureerde interviews gehouden met respondenten van het Openbaar Ministerie en Slachtoffer-

6 In ons onderzoek hebben we zowel officieren van justitie (vier), als advocaten-generaal (drie) geïnterviewd. We gebruiken kortheidshalve de eerste term.

7 We zullen hierna spreken van 'de advocatuur' of van 'advocaten'. De respondenten uit dit onderzoek treden allen op ten behoeve van het slachtoffer; sommigen treden echter ook op ter verdediging van de verdachte.

8 Voor een gedetailleerder verslag van de onderzoeksresultaten: Kool e.a. 2016, hoofdstuk 6.

9 Opgemerkt dient te worden dat de advocatuur destijds niet is bevraagd; het onderzoek van Van Wingerden kende een iets andere opzet dan het voorliggende.

10 P. Davies, P. Francis \& V. Jupp, Doing Criminological Research, Londen: Sage 2011, p. 60 e.v.

11 De methode van semigestructureerde interviews is gekozen vanwege de ruimte die dit biedt om desgewenst dieper in te gaan op kwesties die door de respondenten werden aangesneden; $\mathrm{K}$. Beyens \& H. Tournel, 'Mijnwerkers of ontdekkingsreizigers? Het kwalitatieve interview', in: Kwalitatieve methoden en technieken in de criminologie, Leuven: Acco 2009, p. 195-228.

L.A. Goodman, 'Snowball sampling', Statist 1961, 1, p. 148-170. 
hulp Nederland (SHN). ${ }^{13,14}$ We noemen deze omdat er diverse dwarsverbanden zijn gevonden tussen wat naar voren werd gebracht in de gesprekken over het voortraject en de desbetreffende zittingsfase. Wanneer relevant, wordt daar in het navolgende aan gerefereerd. Om de vergelijkbaarheid van de gespreksresultaten betreffende de besluitvorming ter zitting te bevorderen werd aan de respondenten een casus voorgelegd. Van belang is op te merken dat deze vraaggesprekken betrekking hadden op de praktijk van het civiele schadeverhaal in volle omvang. ${ }^{15}$

Voor beide gespreksrondes is gewerkt met vooraf toegezonden vragenlijsten en werden de gesprekken opgenomen, ${ }^{16}$ waarna deze werden geanalyseerd in NVivo. ${ }^{17}$

\section{Bevindingen in vogelvlucht}

De trendgegevens over de jaren 2010-2014 laten zien dat het aantal strafzaken met $11,2 \%$ is gedaald, ${ }^{18}$ maar dat het aantal voegingen relatief stabiel is gebleven (daling van 2,4\%). Dat levert een lichte stijging van voegingen in strafzaken op van 16,5\% in 2010 naar 18,1\% in 2014. Daarbinnen is een duidelijke verschuiving te zien inzake de ontvankelijkheid: ${ }^{19}$ volgde in 2010 nog voor 32,3\% van de vorderingen een niet-ontvankelijk, in 2014 was dat afgenomen tot 16,6\%. Tegelijkertijd verdubbelde het aantal vorderingen in de categorie gedeeltelijk ontvankelijk/ ontvankelijk (van 29,8\% naar 59,7\%). ${ }^{20}$ Anders gezegd: tegenwoordig volgt nog in slechts één op de vijf zaken een gedeeltelijke of gehele niet-ontvankelijkheid.

Doorslaggevend voor de kans op succes is de kwaliteit van de onderbouwing van de vordering. Als die goed is, staat noch de aard van de schade (materieel of immaterieel), noch de omvang ontvankelijkheid en toewijzing in de weg. Ook andere factoren blijken niet van zwaarwegende invloed te zijn op de besluitvorming. Geopperd wordt wel dat het voeren van verweren de kans op niet-ontvan-

13 Voor een uitgebreide beschrijving: Kool e.a. 2016, hoofdstuk 4. Er zijn nog twee afzonderlijke interviews gehouden die als bijlage staan opgenomen in het rapport. Het betreft een interview met de schaderegelaar van de NS en een vraaggesprek met een schaderegelaar van de politie Oost-Nederland, Gelderland-Zuid. Deze interviews betroffen schadeverhaal in de context van de uitoefening van 'veilige publieke taak'.

14 We gebruiken de term SHN, maar doelen daarmee niet op de institutionele beleidsopvatting, maar enkel op opvattingen van individuele werknemers.

15 Dat lag namelijk anders voor het kwantitatieve onderzoek: dat betrof vier geselecteerde delicten (diefstal, vernieling, mishandeling en verstoring van de openbare orde), afgedaan door de meervoudige kamer in eerste aanleg.

16 Met uitzondering van één interview, respondent weigerde opname.

17 NVivo is een voor kwalitatieve data-analyse ontworpen software. De verwerking is met het oog op de interbeoordelaarsbetrouwbaarheid door ons beiden uitgevoerd, eerst afzonderlijk met een daaropvolgende overlegronde.

18 S.N. Kalidien (red.), Criminaliteit en rechtshandhaving 2015. Ontwikkelingen en samenhangen, Den Haag: CBS, WODC, Raad voor de rechtspraak 2016, tabel 6.1.

19 Tabel uit: Kool e.a. 2016, p. 41.

20 In deze categorie zijn zaken opgenomen die door niet bij dit onderzoek aansluitende registratie niet eenduidig ofwel onder 'gedeeltelijk ontvankelijk' of 'ontvankelijk' konden worden ingedeeld. 
kelijkheid zou doen toenemen, maar dat verband is in het kwantitatieve onderzoek niet aangetroffen.

Voor de materiële schade geldt dat er vaak sprake is van volledige toewijzing en dat het aantal opgevoerde schadeposten niet van invloed is op de ontvankelijkheid. Sterker nog, juist in zaken waarin een behoorlijk aantal schadeposten wordt opgevoerd, groeit de kans op toewijzing. Veel gevonden schadeposten betroffen: apparaten, inkomstenderving, braak- of herstelschade, reiskosten, geld en kleding.

Bij de immateriële schade valt op dat de kans op ontvankelijkheid toeneemt wanneer de vordering enkel betrekking heeft op deze schadecategorie. Een verklaring ligt wellicht in de bescheiden bedragen die werden gevorderd. ${ }^{21}$ Opgemerkt kan worden dat in zaken waarin vergoeding voor zowel materieel als immaterieel nadeel werd gevorderd, de bedragen voor de laatste categorie hoger lagen en de kans op een niet-ontvankelijkheid toenam. Overigens geldt dat vaak minder wordt toegewezen dan gevorderd. Dat geldt met name voor de toewijzing van vergoeding voor het immateriële nadeel; hiervoor geldt dat het Openbaar Ministerie in zijn advies naar beneden bijstelt, waarna de rechter er nog eens wat van afhaalt. Dat stuit bij SHN en de advocatuur overigens op bezwaren, temeer omdat er geen duidelijke redenen voor worden gegeven in het advies en het vonnis. Volgens SHN en de advocaten leidt deze bijstelling tot onbegrip en teleurstelling bij slachtoffers, iets waarvan officieren en rechters zich bewust zijn. Hier werpen in het navolgende te beschrijven verschillen in opvatting over de aard en betekenis van het civiele schadeverhaal hun schaduw vooruit.

\section{De betekenis van de opvatting inzake civiel schadeverhaal}

Dat de professionele opvattingen van invloed zijn op de besluitvorming inzake civiel schadeverhaal via het strafproces is geen nieuw gegeven. ${ }^{22}$ Het hoeft daarom geen verwondering te wekken dat ook ons onderzoek laat zien dat de achterliggende opvatting inzake het civiele schadeverhaal een belangrijk gegeven is. ${ }^{23}$ Taakopvattingen met betrekking tot civiel schadeverhaal en de daarmee samenhangende opvatting over de afstemming tussen de betrokken rechtsgebieden en de verhouding tussen betrokken beroepsgroepen lopen (nog steeds) uiteen. We lichten dat hierna toe. Dat doen we aan de hand van een aantal aandachtspunten

21 De hoogte van de gevorderde en toegewezen bedragen inzake immateriële schadevergoeding hangt samen met de voor het dossieronderzoek geselecteerde categorieën delicten (middelzwaar).

22 Zie: R.S.B. Kool \& M.M. Moerings, De wet Terwee, Deventer: Kluwer 2001; Van Wingerden e.a. 2007; S. van Wingerden, 'Gebrek aan eenheid bij de beslissingen van rechters op de vorderingen benadeelde partij', Trema 2008, p. 62-68. Zie ook: J. Candido, 'De vordering benadeelde partij in het strafproces en de onevenredige belasting van het strafgeding', Trema 2011, p. 354-359, i.h.b. p. 358-359, die stelt dat de rechterlijke taakopvatting van niet te onderschatten belang is.

23 Niettemin moet een slag om de arm worden gehouden, want ook voor dit onderzoek geldt dat hetgeen is gevonden over de opvattingen van officieren van justitie en rechters, dit maal aangevuld met die van advocaten, geen algemene gelding heeft. Daarvoor was de groep respondenten te klein. 
die in de vraaggesprekken aan de orde kwamen respectievelijk daaruit naar voren kwamen.

\subsection{Vooraf: de (kwaliteit van de) voorbereiding}

Voorafgaand aan een beschrijving van de opvattingen betreffende de besluitvorming ter zitting moet worden gewezen op het belang van de voorbereiding. Een zorgvuldige voorbereiding bevordert namelijk de ruimte die de officier, en met name de rechter, bereid is te nemen voor de behandeling van het civiele schadeverhaal. Het belang van een zorgvuldige voorbereiding van de vordering benadeelde partij is dan ook niet te overschatten.

Die voorbereiding vindt veelal plaats met hulp vanuit de Slachtofferlokketten; in minderheid van zaken (veelal de zwaardere strafzaken) wordt de benadeelde partij bijgestaan door een advocaat. Uitgangspunt bij het effectueren van het hulpaanbod vanuit de Slachtofferloketten is dat het slachtoffer actief dient te reageren op het (vroegtijdig) gedane hulpaanbod. Omdat het voegingsproces is ingebed in de werkprocessen van het Openbaar Ministerie en het sterk afhankelijk is van de dynamiek daarvan, kan er echter gemakkelijk een kink in de kabel komen. Aandachtspunt hier is met name de toenemende digitalisering en de problemen met (non-)registratie van de benadeelde partij. Een en ander heeft te maken met de korte termijn die het slachtoffer wordt gegund om te reageren (drie weken). Hoewel het mogelijk is de voeging later alsnog handmatig te registreren, betekent dat wel dat een en ander moet zijn opgemerkt vanuit het Slachtofferloket. Om problemen te ondervangen is voorzien in controlemomenten, die regionaal kunnen verschillen. Collegiale contacten over de grenzen van de betrokken organisaties heen spelen hier een belangrijke rol. Overigens betekent controle door SHN niet meer dan advisering; de inhoud van de vordering is uiteindelijk aan het slachtoffer. ${ }^{24}$ Er wordt melding gemaakt van gebrek aan capaciteit en tijd bij SHN.

Ook vanuit de advocatuur wordt melding gemaakt van problemen in de voorbereidingsfase, in het bijzonder met het tijdig verkrijgen van stukken. Je moet er als advocaat soms 'echt bovenop zitten' om de stukken te krijgen en dat kan, als het complexe schade betreft, een (vroeg)tijdige onderbouwing van de vordering hinderen. Soms leidt dat ertoe dat de vordering pas op een laat moment wordt ingediend. Hier speelt ook het tijdsverloop dat gepaard gaat met het inwinnen van stukken bij experts, psychologen, huisartsen en anderen een rol. Het duurt vaak lang voordat door hen dergelijke verklaringen worden afgegeven. Ook hier lijkt het hebben van persoonlijke ingangen bij SHN en/of het Openbaar Ministerie uitkomst te kunnen bieden. Om zeker te weten dat de vordering bekend is doen de advocaten deze ook zelf aan betrokkenen toekomen.

\subsection{De bijzondere aard van de vordering benadeelde partij}

Hoe dan wordt de vordering benadeelde partij als voorliggende ter zitting gezien? Het beeld dat bovendrijft is er een van de vordering benadeelde partij als rechtsfiguur sui generis. Weliswaar wordt algemeen benadrukt dat het een accessoire, 
civiele vordering betreft, maar wel een die door haar inbreng in het strafproces van kleur verandert. Illustratief is dat civilisten die de overstap maken naar de sectie straf aangeven te hebben moeten wennen aan de strafrechtelijke benadering van het civiele schadeverhaal. Na verloop van tijd onderkennen echter ook zij de zingeving daarvan. Dat ligt anders voor SHN en de advocaten; zij zien de vordering benadeelde partij primair als civiele vordering. ${ }^{25}$ Hoewel het een fundamenteel verschil in opvatting betreft, moet dit niet worden uitvergroot, want over de linie genomen zijn SHN en de advocaten positief over de opstelling van officieren en rechters jegens de benadeelde partij. Op een enkele rechter na onderschrijft iedereen dat het civiele schadeverhaal een vast onderdeel is geworden van het strafproces.

Deze positieve opstelling wordt door meerdere respondenten verklaard vanuit de ernst van het aan de onrechtmatige daad ten grondslag liggende strafbare feit. Sommige rechters geven aan dat de confrontatie met het persoonlijke verhaal van het slachtoffer van invloed kan zijn. Voor anderen geldt dat juist die persoonlijke noot kan aanzetten tot terughoudendheid, want 'als je eenmaal slachtoffer bent van een strafbaar feit, gaan er deuren voor je open'. Maar ook dan geldt dat officieren en in mindere mate rechters zich een eigen oordeel vormen over de vordering benadeelde partij. Zo geven de meeste officieren en rechters aan dat zij de vordering inhoudelijk beoordelen, ook als er geen verweer is gevoerd en dus volgens de civielrechtelijke regels toewijzing zou moeten volgen. Anderzijds wordt ook melding gemaakt van een gemakkelijker omgang met bewijslastverdeling inzake het civiele schadeverhaal. Voorts zouden officieren en rechters volgens eigen zeggen meer bereid zijn tot toewijzing van immaterieel nadeel. ${ }^{26}$ Iets wat de advocaten overigens bestrijden. Soms zelfs kan zo'n actieve opstelling uitmonden in een 'uitnodiging' aan een slachtoffer om ter zitting alsnog een vordering in te dienen. Dat laatste gebeurt overigens wel alleen als daar een goede aanleiding voor is, bijvoorbeeld wanneer sprake is van een het slachtoffer niet te verwijten verzuim bij de voorbereiding.

\subsection{Frequentie en vorm}

Volgens de respondenten wordt door slachtoffers regelmatig schadevergoeding gevorderd in strafzaken. Met enige regelmaat wordt dit pas ter zitting, of vlak daarvoor, duidelijk. Hoewel de wet voeging tot aan het requisitoir toestaat, wordt zo'n late voeging als onwenselijk ervaren: ze doorkruist de regie van de strafzaak zoals deze is voorbereid. 'Het is', zoals een rechter opmerkte, 'gewoonweg niet praktisch' en de kans op niet-ontvankelijkheid neemt toe. Of die daadwerkelijk volgt, is afhankelijk van de complexiteit van de vordering, de mogelijkheid tot verweer en de vraag waarom de vordering pas in een zo laat stadium wordt ingediend. In geval van administratieve verzuimen is de rechter, als opgemerkt, soms 
geneigd het slachtoffer de helpende hand toe te steken, maar daar moet dan wel een goede aanleiding toe zijn.

In de meeste gevallen is de benadeelde partij echter niet aanwezig ter zitting; naar schatting is dat in één op de vier zittingen het geval. De advocaten geven aan dat slachtoffers afstand willen houden, het bijwonen van de zitting zou een te grote emotionele belasting vormen voor het slachtoffer. Niettemin adviseren zij hun cliënten om naar de zitting te komen om de rechter de kans te geven zich op de hoogte te stellen van hun wel en wee.

\subsection{De ontvankelijkheid: accessoriteit onder druk}

De ontvankelijkheid en de daaropvolgende beslissing inzake de toewijzing van de schade zijn, zoals opgemerkt, afhankelijk van de kwaliteit van de vordering. Daarnaast biedt ook de toelichting door de advocaat of de medewerker van SHN aanknopingspunten. Die toelichting kan qua tijdsbeslag wel eens uit de hand lopen volgens rechters; men probeert dan op subtiele wijze aan te geven dat een te uitgebreide, tijdrovende toelichting een indicatie kan zijn voor niet-ontvankelijkheid. Niettemin zijn de advocaten in de regel tevreden over de ruimte die wordt geboden om de vordering van de benadeelde partij toe te lichten. Men maakt dankbaar gebruik van de door de rechter geboden ruimte; vragen zijn welkom, want bieden een ingang voor nadere toelichting. Veelal bereidt men zich voor via een pleitnota, die ter zitting wordt overgelegd. Overigens volgt zelden een kennelijke niet-ontvankelijkheid (art. $333 \mathrm{~Sv}$ ). Weliswaar geven sommige rechters op voorhand signalen af dat 'het niets gaat worden', zodat de officier en advocaat weten dat het niet zinvol is uitgebreid stil te staan bij de vordering, maar de formele beslissing volgt bij de einduitspraak.

Wat betreft de ontvankelijkheid wordt geconstateerd dat het verruimde ontvankelijkheidcriterium (geen onevenredige belasting; art. 361 lid 3 Sv) geen verandering heeft gebracht. Bepalend zijn de aard van de schade, de hoogte van het gevorderde bedrag en/of het al of niet voeren van verweer door de verdachte. Dat laat onverlet dat de meerderheid van de respondenten meent dat de kans op ontvankelijkheid is toegenomen. Maar dat is, zo is het algemene gevoelen, het gevolg van 'de tijdgeest' en 'besefvorming'. ${ }^{27}$ Overigens geven sommige advocaten aan dat er nog veel vorderingen niet-ontvankelijk worden verklaard.

Ongeacht de professionele opvatting over de plaats van het civiele schadeverhaal in het strafproces geven officieren en rechters zonder uitzondering aan dat de toenemende participatie van het slachtoffer druk zet op de gang van zaken in het strafproces. Dus ook op het civiele schadeverhaal. ${ }^{28}$ Het managen van de zitting is complexer geworden en de rechter 'moet alle ballen in de lucht houden'. Dat geeft sommige rechters aanleiding tot een striktere invulling van de ontvankelijkheid; voorkomen moet worden dat de kwestie van het schadeverhaal de strafvordering

27 Zie over de 'pragmatiek' van de rechterlijke besluitvorming ook: R. Hartendorp, 'Alledaagse rechtspraak: een pragmatische kijk op oordeelsvorming', Rechtstreeks 2009, 2.

28 In deze zin ook B.F. Keulen, 'Het slachtoffer en de modernisering van het Wetboek van Strafvordering', Strafblad 2015, p. 240-252. Volgens Keulen is de vordering benadeelde partij haar accessoire status inmiddels ontgroeid. 
overschaduwt. Hierbij heeft men niet alleen oog voor de positie van de verdachte, maar ook voor die van het slachtoffer. Want biedt de voegingsprocedure wel voldoende ruimte aan de benadeelde partij? In dit verband wordt gewezen op de tijdsdruk waaronder de (voorbereiding van de) zitting staat: de focus ligt daarbij immers vooral op de tenlastelegging.

\subsection{De aard van de schade}

Volgens de respondenten is de aard van de schade van invloed op de ontvankelijkheidsbeslissing. Men geeft aan dat immaterieel nadeel lastig ligt. Rechters zeggen dat er 'veel tijd wordt gestoken' in de beoordeling van de immateriële schade, waarbij ook de ernst van het delict een rol speelt. Dat laatste wordt bevestigd door advocaten, die aangeven dat hoe ernstiger het delict, hoe groter de kans op ontvankelijkheid. Daarbij geldt dat materiële schade makkelijk is bij te stellen, 'maar voor immateriële schade is het heel vaak gewoon het verhaal van het slachtoffer dat wordt overgenomen'. Het is een gevoelskwestie: 'We doen allemaal wat we redelijk vinden en redelijkheid is een heel vaag criterium', aldus een rechter. Het gebruik van oriëntatiepunten wordt afgewezen, want iedere zaak staat op zich.

Wat de onderbouwing betreft geldt dat de meeste rechters zich richten op de Smartengeldgids en de lijst van de Letselschaderaad, maar dat dit niet meer dan richtsnoeren zijn. De Smartengeldgids zou bovendien de nodige vraagtekens opleveren. Voor de materiële schade geldt dat het Openbaar Ministerie bij minder ingewikkelde schades wel adviseert aan de hand van de BOS-schade, zij het dat men oog heeft voor de wenselijkheid van differentiatie; 'iedereen is anders'. Dat laat onverlet dat je voor bepaalde vaste, terugkerende posten wel met richtbedragen kunt werken. Bij dit alles geldt dat officieren en rechters aangeven dat gewaakt moet worden voor overspannen verwachtingen bij slachtoffers. De advocaten geven echter op hun beurt aan dat rechters en officieren zich niet altijd voldoende lijken te beseffen dat het voor een gemiddeld slachtoffer veel tijd, energie en geld kost om de schade via het civiele recht te verhalen. Ook de teleurstelling over de negatieve beslissing van de strafrechter draagt eraan bij dat slachtoffers de civiele route niet zullen doorzetten.

\section{6 (Gebrek aan) motivering}

Aandachtspunt ook is dat het vonnis vaak onvoldoende uitleg biedt over de redenen voor de (gedeeltelijke) niet-ontvankelijkheid of de bijstelling van de vordering naar beneden. Dat wordt geconstateerd door SHN en advocaten, maar blijkt ook uit het dossieronderzoek. Omwille van de rechtsvorming zou uitgebreidere motivering wenselijk zijn volgens SHN en advocaten. Bovendien, waar maatwerk wordt geleverd in de vorm van een zorgvuldig opgebouwde vordering, is het wel zo netjes om duidelijk aan te geven waarom die niet-ontvankelijk is of geheel wordt toegewezen.

Rechters bevestigen dat veelal wordt volstaan met een standaardmotivering. Men ziet ook niet hoe dat anders zou kunnen, want de aanleiding tot de niet-ontvankelijkheid is immers dat de strafrechter niet goed kan overzien wat de gevolgen van de behandeling van de vordering zouden zijn voor het strafgeding. 'Om uit te 
leggen waarom ik het te moeilijk vind, dat vind ik best ver gaan', aldus een rechter.

\subsection{Oplegging schadevergoedingsmaatregel}

Het advies van de Raad voor de rechtspraak om in geval van toewijzing van (een deel van) de vordering tot schadevergoeding een schadevergoedingsmaatregel op te leggen wordt door de rechters opgevolgd, veelal conform het advies van de officier. Ambtshalve oplegging gebeurt wel eens, maar niet vaak. Je weet als officier en rechter immers ook niet of het slachtoffer wel schadevergoeding wenst, en evenmin weet je wat de aard en omvang van de schade precies is.

Toewijzing van de vordering benadeelde partij en daaraan gerelateerde oplegging van de schadevergoedingsmaatregel gaat overigens gepaard met hoofdelijke aansprakelijkheid, zij het dat een uitzondering wordt gemaakt voor jeugdige daders. Gebrek aan draagkracht is (overigens ook bij volwassen daders) veelal geen reden tot matiging, maar kan eventueel wel aanleiding geven tot het volstaan met het opleggen van vervangende hechtenis tot één dag. Dit om te voorkomen dat de vervangende hechtenis als straf gaat fungeren; hiervoor geldt dat de eerder opgetekende bezwaren nog steeds opgeld doen. ${ }^{29}$

\subsection{De casus}

De voorgelegde casus was afgeleid van een voor het kwantitatieve onderzoek geselecteerd dossier en werd qua feiten door onderzoekers aangevuld. Kort gezegd ging het om een woningoverval op echtgenoten die beiden blind waren. De buit bestond uit een gering geldbedrag en enkele sieraden. Namens de slachtoffers was één vordering benadeelde partij ingediend. Zij vorderden een klein geldbedrag aan materieel nadeel (gestolen geld en sieraden) en een bescheiden bedrag aan immaterieel nadeel ( $€ 750$ wegens geleden vrees en slapeloosheid). De onderbouwing van de vordering bestond uit een opgave van een juwelier van de geschatte waarde van de gestolen sieraden en een door de slachtoffers geschreven korte verklaring dat zij slecht sliepen en angstig waren als gevolg van de woningoverval.

De oorspronkelijke casus werd met twee varianten aangevuld, eerst met het overlijden van het echtpaar en hun blindengeleidehond als gevolg van de woningoverval, en daaropvolgend met de ontdekking van het strafbare feit door hun dochter, die daarvoor vergoeding van shockschade vordert. In de tweede variant wordt een schadepost opgevoerd voor de te vervangen blindengeleidehond ( $€ 18.000)$ en werd de vordering tot vergoeding van immateriële schade verhoogd tot $€ 8000$ vanwege het verdriet over de overleden hond. De casus vermeldt niet of er een prijsopgave wordt gedaan of een aankoopnota wordt overgelegd. De derde variant ten slotte, wordt aangevuld met een vordering wegens shockschade door de dochter ( $€$ 10.000). Dat laatste wordt onderbouwd door een brief van de huisarts, waarin staat vermeld dat de dochter naar aanleiding van het strafbare feit wekelijks een psycholoog bezoekt en kalmerende medicijnen neemt. Er wordt in geen van de varianten verweer gevoerd door de verdachte. 
Voorop gesteld zij dat alle respondenten aangaven meer informatie nodig menen te hebben om de vordering te kunnen beoordelen. Met name de advocaten tonen zich kritisch over de huns inziens te summiere onderbouwing van de vordering. Zo wijzen zij erop dat de voor de hand liggende post van de begrafeniskosten opgevoerd had moeten worden. Voor het overige lopen de door de verschillende beroepsgroepen gegeven antwoorden echter niet sterk uiteen. Het feit dat slechts één vordering was ingediend vindt men bezwaarlijk, maar niet onoverkomelijk. Respondenten problematiseren allen dezelfde elementen (causaliteit, relativiteit, geen grondslag voor toewijzing shockschade), en zijn het in meer of mindere mate eens over de (niet-)ontvankelijkheid en hoogte van de toe te wijzen bedragen.

In de eerste variant wordt de summiere onderbouwing van het immateriële nadeel van het echtpaar niet problematisch gevonden; het zijn voorzienbare gevolgen en het betreft een schappelijk bedrag. De tweede variant levert meer vragen en twijfels op, want valt het overlijden van de hond wel onder de strekking van de ten laste gelegde woningoverval (relativiteit)? Ook wil men onderbouwing zien voor de aankoopprijs van een nieuwe hond en roept het immateriële nadeel dat zou zijn geleden vanwege het overlijden van de hond bij sommigen vraagtekens op.

Het grootste struikelblok echter ligt in de shockschade die wordt opgevoerd in de derde variant. Met name het causale verband wordt geproblematiseerd (rechtstreeks verband). Officieren en rechters geven aan dat shockschade in de regel niet wordt gevorderd via de voeging benadeelde partij. Men toont zich terughoudend en wijst op de door de Hoge Raad gestelde eisen van een zorgvuldige onderbouwing. Daarnaast wijzen officieren en rechters op de onvrije positie van de verdachte. Die voert weliswaar geen verweer tegen de vordering, maar hij heeft gelet op zijn processuele positie ook niet de volle ruimte om tegen de vordering in het geweer te komen. Overigens vinden ook de advocaten dat de vordering ter zake van de shockschade onvoldoende is, daar had een 'DSM 4- of DSM 5-diagnose' bijgevoegd moeten worden. Anderzijds vinden zij het in de eerste twee varianten door het echtpaar gevorderde smartengeld, dat door officieren en rechters als schappelijk wordt beschouwd, te laag.

\subsection{Actoren over actoren}

Ten slotte hebben we ook de vraag gesteld naar hoe de professioneel betrokkenen de omgang van de andere beroepsgroepen met civiel schadeverhaal waarderen. Over de linie genomen is sprake van wederzijdse waardering. Niettemin is er ook kritiek. De grond daarvoor is gelegen in een fundamenteel verschil in opvatting over de aard van de vordering benadeelde partij.

SHN en de advocaten zien de vordering namelijk als een civiele kwestie en benadrukken dat maatwerk dient te worden geleverd. Dat brengt mee dat men (ten behoeve van het slachtoffer en de rechtsvorming) duidelijke antwoorden wil op de vraag waarom een vordering niet-ontvankelijk wordt verklaard en schadeposten niet worden toegewezen of beperkt; ook tarifering wordt hiermee afgewezen. In het verlengde hiervan zou vanuit de advocatuur meer openheid van de kant van het Openbaar Ministerie op prijs worden gesteld. Openheid van zaken betref- 
fende het standpunt inzake de vordering geeft de advocaat gelegenheid de verwachtingen van het slachtoffer op voorhand te temperen.

Maar ook naar de rechter toe wordt door advocaten en SHN gewag gemaakt van gebrek aan eenduidigheid in de besluitvorming. Geconstateerd wordt dat civiel schadeverhaal een 'mensendingetje' is: weliswaar toont de rechter over de linie inmiddels een rekkelijke opvatting over civiel schadeverhaal, maar de opvattingen lopen nog steeds uiteen. Ook een enkele officier wil zich nog wel eens te strikt opstellen is de indruk. Hier wordt een koppeling gemaakt met het niveau van kennis van het civiele recht, met name binnen het Openbaar Ministerie zou hier een verbeterpunt liggen. Maar ook het niveau van civielrechtelijke kennis van de rechter leidt volgens advocaten tot verschil in uitkomsten. Niettemin maken advocaten melding van goede professionele contacten met officieren; men weet elkaar te vinden wanneer dat nodig is.

In reactie op de kritiek vanuit SHN en de advocatuur wijzen rechters en officieren op de begrenzingen van het strafgeding. Zij onderschrijven de civiele aard van de vordering, maar binnen de context van het strafgeding is er volgens hen geen ruimte om op de door SHN en de advocatuur gewenste gedetailleerde wijze te reageren. Rechters die een civiele achtergrond hebben, worstelen daar weliswaar mee, maar gaan uiteindelijk overstag, want de strafvordering zet de toon van het geding. Rechters en officieren geven aan binnen de bandbreedte van de onevenredige belasting maatwerk te leveren. In dit verband ook kan worden opgemerkt dat rechters enige afstand nemen van het advies van het Openbaar Ministerie, omdat dit zich soms te veel zou laten leiden door het belang van het slachtoffer. Het advies wordt gewaardeerd, maar is volgens rechters niet doorslaggevend.

Officieren en rechters maken bovendien de tegenwerping dat SHN en de advocatuur te weinig doen aan verwachtingsmanagement. Benadrukt wordt dat dit gelet op de beperkingen van het strafproces noodzakelijk is, en dat de opstelling van SHN en de advocatuur risico's op teleurstellingen met zich brengt voor slachtoffers. Er is waardering voor de slachtofferadvocatuur, maar tegelijkertijd wordt ook een opdrijvend effect geconstateerd, dat niet altijd wordt geapprecieerd.

\subsection{Het niveau van expertise}

Officieren van justitie geven aan dat er voldoende kennis aanwezig is binnen het Openbaar Ministerie; iets wat van de zijde van de advocaten wordt bestreden. Moeilijkere zaken worden opgelost door te rade te gaan bij collega's die op civielrechtelijk gebied 'meer dan gemiddeld' zijn. Een enkele officier meent niettemin dat er vanuit de organisatie qua permanente educatie te weinig gebeurt.

Rechters koppelen het kennisniveau binnen hun eigen beroepsgroep aan de achtergrond van de individuele rechter. Echte strafrechtmensen zouden zich altijd wat onzeker voelen op het terrein van het civiele schadeverhaal, ofschoon ook wordt opgemerkt dat 'iedereen steeds beter in die materie is ingevoerd'. Bij roulatie naar de sectie straf doe je er als rechter goed aan 'de instructie van Candido' te 
bestuderen, want voeging komt vaak voor. Interne bijscholing vindt plaats via een college/werklunch, verzorgd door een civielrechtelijk onderlegde collega. ${ }^{30}$

Feitelijk gelden alleen voor de advocatuur permanente opleidingseisen. Toevoeging voor rechtsbijstand aan de benadeelde partij vereist dat je (minstens) de basiscursus hebt gevolgd.

\section{Afsluiting: vooruitgang geboekt, maar waakzaamheid geboden}

Het voorliggende onderzoek sluit aan op uitkomsten van eerder onderzoek. Wie kennisneemt van voorgaande evaluaties ziet dat er sprake is van vooruitgang, maar ook van blijvende beletselen. Waar de invoering van de Wet Terwee destijds als omslagpunt gold, is de strafrechtspraktijk inmiddels gewoon geraakt aan civiel schadeverhaal en wordt dit breed geaccepteerd. In die zin zijn de opvattingen zeker veranderd ten gunste van het slachtoffer. Tegelijkertijd geldt dat de wijziging van het ontvankelijkheidscriterium ex artikel 361 lid 3 Sv niet heeft geleid tot de door de wetgever beoogde verruiming. Of wellicht beter gezegd: het is niet de wijziging van het wettelijk criterium dat tot verruiming heeft geleid, maar de geleidelijke gewenning aan het fenomeen en de acceptatie daarvan binnen de strafrechtspleging. Duidelijk is dat dit samenhangt met de groeiende erkenning van de belangen van het slachtoffer en diens positie als procesdeelnemer. De strafrechtspleging kan, maar wil ook, niet om het slachtoffer heen. Tegelijkertijd roept dat zorg op voor het behoud van een gewaarborgd strafproces, welke zorg uitstraalt op de omgang met het civiele schadeverhaal.

Hoe de afwegingen over het civiele schadeverhaal in concreto uitvallen, is bovendien afhankelijk van factoren als de omstandigheden van de zaak, de aard van het delict, de aard en hoogte van de schade, de aanwezigheid of afwezigheid van (rechts)bijstand voor de benadeelde partij en de mate waarin verweer wordt gevoerd tegen de vordering tot schadevergoeding. Al die factoren bepalen, in samenhang met de taakopvatting, de kans van slagen voor de benadeelde partij. ${ }^{31}$ De kwaliteit van de voorbereiding vormt daarbij, zoals opgemerkt, een belangrijk aandachtspunt. Concluderend geldt dat het voorliggende onderzoek uitwijst dat er winst is geboekt ten opzichte van 2007, maar tevens dat de kwestie van het civiele schadeverhaal ook in de nabije toekomst tot hoofdbrekens zal blijven leiden. Zeker wanneer dit wordt beschouwd in samenhang met de groeiende slachtofferparticipatie.

31 Zie over de 'pragmatiek' van de rechterlijke besluitvorming ook: Hartendorp 2009. 